\title{
Algorithms for Mediation Restorative Work of the Territorial Reconciliation Service in Difficult Cases
}

\author{
Elena V. Belonogova and Natalya G. Prokopyeva* \\ Department of Mediation and Restorative Practices \\ of the Kuzbass Regional Centre for Psychological, Medical and Social Care \\ Kemerovo, Russian Federation
}

Received 15.01.2020, received in revised form 22.01.2020, accepted 07.02.2020

\begin{abstract}
The article presents the experience of the Territorial Reconciliation Service of the Kemerovo Region in the development and testing of algorithms for mediation resolution of complex school and family situations of minors based on the principles of the restorative approach. For restorative work with multi-level conflicts in the escalation stage in educational organizations, as well as difficult life situations of minors and their families, registered in the juvenile affairs departments, special social technologies have been developed that have a comprehensive design and include various restorative programmes (restorative mediation, community circle, school-parent council, family group conference, family mediation). An analysis of the results of pilot empirical testing of the technologies developed by the authors shows their effectiveness in relation to complex school and family conflict situations. If there is special training in restorative technologies and an organizational structure uniting trained restorative practitioners (Territorial Reconciliation Service), these algorithms can be applied by specialists in the social sphere, education system, juvenile delinquency prevention and neglect system.
\end{abstract}

Keywords: complex multi-level conflict, territorial reconciliation service, mediation method, restorative approach, principles of restorative justice, restorative programma, community circle, family conference, school-parent council, family mediation, restorative mediation.

Research area: social sciences.

Citation: Belonogova, E.V., Prokopyeva, N.G. (2020). Algorithms for mediative restorative work of the Territorial Reconciliation Service in difficult cases. J. Sib. Fed. Univ. Humanit. Soc. Sci., 13(2), 179190. DOI: $10.17516 / 1997-1370-0549$.

(C) Siberian Federal University. All rights reserved

* Corresponding author E-mail address: lebel12018@yandex.ru, skei5421@yandex.ru 
The social and psychological well-being of society is associated with the prevailing ways of responding to problem situations that arise at different levels, such as interpersonal, group (within one community), intergroup (between different communities), when normal communication between their participants is difficult or destroyed: conflict (in the family, school, at the enterprise, another organization), criminal (falling under the articles of the criminal code) and quasi-criminal (the harm done does not fall under the criminal article). The main typical ways of responding to such situations existing in Russian society in individual and collective consciousness, institutional practices can be described as administrative (decisions from above), power (argument outside the legal field) and punitive (stigmatization, punishment). In education, pedagogical (educational conversation) and psychological ones (diagnosis and correction of psychological deficits that determine behaviour) are added to them. In the work of social services this is a correctional and rehabilitation way: they draw up a preventive correctional and rehabilitation program for a child and a family in a difficult life situation, based on the expert opinion of specialists (Maksudov, 2017; Karnozova, 2014; Konovalov, 2017).

Studies of domestic and foreign authors show the ineffectiveness of these methods of response in relation to aspects significant for the participants in the situation and society: the cessation of hostility and prosecution; restoration of justice; exemption from negative psycho-emotional states; positive changes in social behaviour; prevention of relapse offenses. In addition, there are negative consequences of the effect of stigmatization and isolation from society, causing difficulties in the positive self-identification and socialization of the offending individuals and forcing them to join the antisocial and criminal groups (Braithwaite, 2002). Interaction with representatives of law enforcement and judicial authorities is traumatic not only for the offenders, but also for the victims: participation in investigative action and in the trial is fraught with retraumatization for them, because in a competitive judicial system, the needs and psycho-emotion- al states of the victims are not taken into account (Zehr, 1998; Karnozova, 2014). And most importantly, the participants in the situation themselves are not its subjects, they are just an object, "material", with which specialists from various structures and services work, making decisions and depriving people themselves of the opportunity to resolve the situation and influence significant aspects of their life (Christie, 2007), which contributes to the formation of a pessimistic worldview, a dependent position, learned helplessness.

An analysis of the activities of education specialists, social services and bodies of the prevention system shows that the personal dynamics of participants in problematic life situations with typical domestic and institutional forms of social response to conflicts and offenses is not positive in terms of developing an understanding of oneself, the situation, the opponent, other participants, taking responsibility for their actions to create and correct the situation, for their future choices; coping with negative conditions (shame, fear, guilt, anxiety); restoration and development of positive self-identity; restoration of communication, trust and constructive dialogue with the opponent; establishing constructive relations with the social environment, community. As a result, there is no understanding of the situation, no rethinking of one's and other participants' behaviour, no extraction of meaning and lesson for the future from what happened. That is, the methods existing in society for a typical response to situations of interpersonal, social and criminal conflicts do not only completely resolve the problem situation itself, but also do not contribute to positive personal and social changes in its participants or cause dysfunctional changes, which affects the psychological quality of life of participants situation, and the degree of socio-psychological well-being of society as a whole, contributing to the growth of social tension (Braithwaite, 2002; Karnozova, 2014; Konovalov, 2017; Maksudov, 2017; Vosstanovitel'nye program$m y . . ., 2018)$. This is especially significant for minors, whose personality structures are susceptible to change, which affects their future life choices, social behaviour, and the ability 
of young people to cope with conflicts in their personal and professional lives. In addition, the lack of positive experience in the peaceful resolution of conflicts makes them vulnerable psychologically.

In the educational environment, acute unresolved conflicts sometimes turn into a tragedy: a child faces school maladaptation and psychological trauma, which can result in a violation of discipline, absenteeism, poor performance, suicidal attempts, aggressive or neurotic manifestations, the use of psychoactive substances, offenses; teachers face with loss of trust and status, dismissal, serious stress with its negative consequences for mental, physical and social well-being.

The restorative approach to responding to conflict and criminal situations is based on the mediation method (peace negotiations with the participation of an independent neutral mediator, not making decisions) and the principles of restorative justice (Zehr, 1998): restoring understanding and dialogue; autonomy and responsibility of the participants in the situation for its resolution, correction of consequences and prevention of future repetition; repairing the harm; getting rid of negative conditions, supporting a healthy personality identity and a ban on stigmatization; community responsibility for supporting positive changes in the behaviour of participants in the situation (Karnozova, 2014; Konovalov, 2017; Maksudov, 2017). An important feature of the approach is the active role of the participants in the situation, all interested members of the communities in its peaceful and constructive settlement, which is based on the values of mutual understanding, joint search that is acceptable for each solution, recognition of the significance, responsibility and contribution of each to its implementation (Page, 2011; Costello, Wachtel, Wachtel, 2009; Pranis, Stuart, Wedge 2010; Karnozova, 2014; Konovalov, 2017; Maksudov, 2017).

The Russian model for resolving conflict, criminal, difficult school and family situations involving minors based on the principles of the restorative approach is called the Reconciliation Service. The service can be created at the level of a separate educational organization - school service (Konovalov, 2017; Metodicheskie rekomendatsii po sozdaniiu..., 2015) or on the basis of a municipal institution - territorial service (Konovalov, 2017; Territorial'nye sluzhby..., 2015). Territorial Reconciliation Service (TRS) is the organizational structure for the implementation of restorative justice in relation to juvenile delinquency, difficult life situations of a minor and their family; it works with criminal situations involving minors, complex conflicts, including the administration of an educational organization. It is created on the basis of a municipal organization in the system of education or social protection. TRSs can implement various programmes: mediation, community circles, family conferences, etc. (if trained by service specialists). TRSs provide methodological support for school reconciliation services, and monitor their activities in this territory (Territorial'nye sluzhby..., 2015).

Based on of the Department of mediation and restorative practices of the Kuzbass Regional Centre for Psychological, Medical and Social Care, TRS has been functioning at the level of the city of Kemerovo and the Kemerovo region for about 8 years. The Service works in difficult situations in the family and educational organizations on appeals received from directors of educational organizations, municipal education authorities, the Commissioner for Children's Rights, units for minors, etc. Typical situations for TRSs are:

1) Complex multi-level conflicts in the stage of escalation in educational organizations (bullying in relation to the "uncomfortable" child and their parents);

2) Minors and their families in difficult life situations (conflict with the law and environment, broken family ties, neglect, conflicts and family abuse).

The authors of the article have developed technological algorithms for mediation restorative work to resolve such situations. The possible algorithms of complex restorative work for the two main categories of cases outlined above, tested in a pilot empirical study, are presented below. The first presents the option of an appeal from the school principal; the second presents the interaction with the Juvenile Division. 
A typical situation of the first category is a multi-level conflict in the stage of escalation in an educational organization: the conflict has gone beyond the scope of the primary incident, includes several parties, it involves students, parents, teachers, specialists, it has already gone beyond the boundaries of the educational organization (statement to the police, complaints to the department of education, appeal to the prosecutor's office). Usually there is bullying at the level of the class, the parent community, teachers and even the school administration regarding the "uncomfortable" child and his parents, it is difficult for teachers to find an approach to such a child, to help him join the peer community:

- In kindergarten and elementary school - a child with "features", for example, attention deficit hyperactivity disorder, autosimilar behaviour, other neurological problems, who has weak emotional-volitional and behavioural regulation and / or learning problems;

- At the middle school - a shy / withdrawn child, with a lower social and / or financial status of the family than other children have, or a child of a different culture that peers do not want to accept;

- At the senior level - an extraordinary child who stands out against the background of others who "cleverly" asks too many provocative questions, "shakes the law", makes comments to teachers;

- A child whose parents "push for their rights", require special treatment from the school, write complaints to the principal and to higher authorities (Belonogova, 2019).

When the administration and teachers do not cope with the situation in the classroom and school with their usual methods, they implicitly organize "pressure through the collective" on the child and / or "pressure through the parents" on the parents of this child, creating an unbearable situation for them and "squeezing" the child out of the class and the school.

Analysis and generalization of the work experience of TRS in complex cases made it possible to distinguish the following components of the design of the restorative program: the boundaries of the situation (the subject area of social reality with which restorative mediators work on this case); participants in the restorative programma; sequence and stages of restorative work (model); types of specific related restorative programmes; team of restorative mediators and their position; organizational support of restorative work; management of restorative work according to the situation (case management); normative and documentary support of case work (Belonogova, 2019).

After receiving an application to the TRS, mediators analyse it for the possibility of resolving the situation in a restorative way, contact the school principal by telephone, inform him / her of the essence and principles of restorative work, and arrange a meeting at a convenient time for everyone. An alliance with the director is very important so that he / she is "on the side of solving the problem" and organizationally helps the TRS to carry out restorative work. Based on the results of the meeting, they draw up an agreement on interaction and cooperation between the TRS and the school.

To determine the boundaries of the situation and the model of restorative work, mediators conduct preliminary meetings in the following order: with the school principal; with the school administration and specialists; with the form teacher in the class where the conflict arose first; with teachers working in the classroom; with the parents of the child / children who are being bullied / discriminated against; with other parents of the class; with a child / children who are exposed to bullying, discrimination or confrontation; with the rest of the class, possibly in separate groups.

At the beginning of each meeting, the participants are explained the essence and principles of restorative work on conflict situations, the role of mediators of TRS and the responsibility of participants in resolving the situation. Then the participants are given the opportunity to tell about their vision of the problem situation and its consequences for them and other people included in the situation, about the most important thing in the situation for them personally, what is important for them to change or decide, about their vision of possible solutions to the situation, what they are ready to do for this personally (Belonogova, 2019). 
In conclusion, they are proposed to take part in a peaceful settlement of the situation in a restorative way through participation in the restorative program, its rules and procedure, the role of all participants and mediators are explained, if necessary, a written consent to participate is taken.

After the preliminary meetings, the mediators draw up a plan of restorative work on the case with a description of the successive steps to resolve the situation, the responsibility of the TRS and the school for each item, signed by the head of the TRS and the school principal.

Documentary support of work on a complex multi-level conflict in a school may include:

1. An application from the school for assistance in resolving a conflict situation;

2. An agreement with the school to conduct a restorative program;

3. A plan of restorative work;

4. A written consent to participate in mediation procedures or a written refusal (if necessary);

5. Agreements on the results of specific restorative programmes - community circles, mediation, school-parent council;

6. A protocol of the restorative work (without confidential information).

The protocol and all final agreements remain at the school and the TRS (Belonogova, 2019).

The model of work on the restorative resolution of the situation of a complex multi-level conflict (developed on the basis of methodological materials of Putintseva N.V. and Konovalova A.Iu., Moscow) is based on the following components:

1. The Community circle with representatives of the administration and school specialists;

2. The Community circle with teachers of the "problem" class with the participation of the school principal;

3. The Community circle with the parents of the "problem" class;

4. The Community circle with students of the "problem class";

5. Restorative mediation between specific participants in the situation who personally confront each other regardless of Circles and at any stage;

6. School-parent council;

7. Family mediation or Family conference (if the situation is difficult in the family of the child);

8. A cycle of classes in constructive communication skills for students and constructive pedagogical communication skills for teachers (can be carried out by guidance counsellors of the school itself or the Kuzbass Regional Centre for Psychological, Medical and Social Care) (Belonogova, 2019).

Let us describe the essence of some restorative programmes, which may be part of the model of work in complex school situations.

Community circles are a centuries-old method of conflict resolution that exists in the culture of many nations: participants in a conflict or criminal situation, referring to the traditions of reconciliation, jointly decide how to change the situation in the interests of everyone so that this contributes to the realization of moral values. The most important feature of the Circles is the involvement of all interested people in the discussion of the problem, which ensures their active participation in decision making and sharing of responsibility for its implementation. The Circle process allows you to include a significant number of participants in working with conflicts and criminal situations (Costello, Wachtel, Wachtel, 2009; Maksudov, 2017; Metodicheskie rekomendatsii po vnedreniiu..., 2017; Metodicheskie rekomendatsii po sozdaniiu..., 2015; Pranis, Stuart, Wedge, 2010). A typical Circle consists of several rounds:

- Updating of values (the question depends on the category of participants);

- Vision of the situation by the participants ("the problem speaks with the voices of people");

- Search for a solution (ways out of the situation);

- Responsibility (what everyone is ready to do to solve the situation). The decisions of the Circle are recorded on the paper, signed by the participants, photographed, and then entered into the protocol (Maksudov, 2017).

School-Parent Council, SPC (Konovalov, 2017), is a version of the Community Circle 
on a situation affecting interpersonal, family, managerial problems, in which all parties involved in the conflict take part: administration, teachers, specialists, parents, students, and if the situation goes beyond schools, it involves specialists of the authorities of the prevention system (Minors Affairs Department, Commission on Juvenile Affairs and the Protection of Their Rights, education management bodies). SPC and Community circles with teachers and parents of the class, in addition to solving a specific conflict situation, can contribute to:

- Inclusion of all participants in the situation in equal open communication, which does not allow manipulation, threats, moralization, pressure, blackmail, stigmatization and other destructive influences;

- Joint definition of educational strategies for class children;

- Formation of a responsible parental position and professional position of teachers and school specialists, coordination of their actions;

- Establishment of traditions of peaceful living of children, parents, teachers, administration and specialists in the school space (Konovalov, 2017).

Restorative mediation is a process in which a mediator creates the conditions for restoring people's ability to understand each other and agree on acceptable options for resolving problems (if necessary, on repairing the harm caused) resulting from conflict or criminal situations (Maksudov, 2017; Karnozova, 2014; Metodicheskie rekomendatsii po vnedreniiu..., 2017; Metodicheskie rekomendatsii po sozdaniiu..., 2015). It is important that the parties have the opportunity to free themselves from negative states and find a resource for a joint search for a way out of the situation. It includes preliminary meetings of the mediator with each of the parties separately and a general meeting of the parties with the participation of the mediator. The agenda of the joint meeting includes issues that are important for the parties and agreed with them. Based on the results of the meeting, a mediation agreement is drawn up. It is effective for conflicts between participants in educational relationships, situations of harm (Maksudov, 2017).
It is important that after the end of the restorative work of TRS mediators on a specific conflict, the school "learns a lesson", the director regains managerial control over the situation in the organization, the form teacher regains pedagogical control over the situation in the classroom, and parents regain control over their relationship with the child. And also it is important that all participants in the situation take responsibility for changing their behaviour, so that similar situations do not recur in the future (Konovalov, 2017; Belonogova, 2019).

Over the past 3 years, all Kuzbass TRSs have successfully resolved 420 situations, of which more than 300 were difficult school situations. The analysis of feedback questionnaires shows the satisfaction of participants with the manner and result of resolving these situations.

In 2018, TRSs began interacting with juvenile departments in the city of Kemerovo. A normatively new area of work at the regional level is determined by the Agreements on the interaction between the Main Directorate of the Federal Service of Punishment fulfillment of the Kemerovo Region and the Kuzbass Regional Centre for Psychological, Medical and Social Care, on cooperation and interaction between the Main Directorate of the Ministry of Internal Affairs of the Russian Federation for the Kemerovo Region and the Regional Department of Education and Science.

According to the agreements, the Kuzbass Regional Centre for Psychological, Medical and Social Care works to prevent the neglect and delinquency of children and adolescents, as well as to provide assistance and support to minors in socially dangerous situations or difficult life situations. One of the tasks of the work is the formation of juvenile non-violent methods of communication and tolerant attitude towards others. As many Juvenile Division experts note, the disadvantage of minors in most cases is associated with an unfavourable situation in their family (conflict, psychoactive substances abuse by parents, authoritarian upbringing, or excessive child custody, etc.).

Therefore, TRS specialists began to organize and carry out restorative programs with minors and their families, which were in 
the focus of the Juvenile Division, for which a special algorithm for the restorative work in difficult life situations of minors and their families registered by the Juvenile Division was developed.

To organize the interaction between the TRS and the Juvenile Division, a specialist Natalya Prokopyeva conducted informational consultations with the Juvenile Division inspectors in each city police department in order to inform them of the principles of the restorative approach, the possibility of sending a minor and their family to restorative work and the procedure for carrying it out, as well as methods of recording the results of work. A circle of problems was discussed and identified with which the Juvenile Division inspector can send minors and their parents / legal representatives to the TRS to work with them on restorative technologies. That is, the idea was formed that participation in restorative programmes helps people feel heard and understood, restore relationships in the family (which for various reasons, family members can't do without assistance), apologize and accept an apology, make amends, plan the future, without repeating such situations, enlist the support of relatives and a significant social environment. But to achieve this, you need a neutral party, and a TRS specialist can be that one.

The Juvenile Division inspectors were also informed about the principles of the procedure itself for conducting mediation restorative programs:

- Voluntary participation of the parties. Despite the fact that the inspector of the JD (Juvenile Division), having written the "Application", provides for the obligatory initial visit of minors and his parents to the department, as well as of other persons significant for the minor, whose participation is important and appropriate, the parties further participate in the work voluntarily. Coercion in any form is unacceptable. The parties have the right to refuse to work both after the first visit to a TRS department, and during the program.

- Confidentiality. TRS specialists do not disclose information regarding the content identified in the process of restorative meetings. The exception is information related to a possible threat to life or the commission of a crime. Then the TRS specialists inform the participants that the information will be disclosed.

- Neutrality and independence of TRS specialists. The restorative programmes facilitator do not propose solutions, do not take sides, including the side of law enforcement agencies or other organizations, and do not work in their interests, but they rely on the principles of restorative justice and equally support the parties in their desire for a constructive resolution of the situation.

- Responsibility and cooperation of the parties. The parties, when searching for options for resolving the situation, cooperate with each other in order to achieve the final result, jointly seek a solution to the problem. However, neither side has advantages. The parties have an equal right to express their vision, ask questions, and individually speak with a TRS specialist in the process of mediation.

- Repairing the harm. If harm was caused to either side (to each other), the participants discuss options for making amends to the offender - if he / she is a minor, then it is important to discuss their contribution to correcting the situation, making amends as much as possible with their forces.

- Responsibility. Restorative programmes facilitator is responsible for the safety of participants in the meeting process, for observing the principles of the restorative approach, the procedures for holding a joint meeting. The responsibility for the outcome of the meeting and for decisions taken lies with the parties to the conflict. A TRS specialists cannot advise the parties to make a decision on a conflict objectively.

The work with juveniles registered with the Juvenile Division and their families is carried out free of charge and only if the Juvenile Division inspector writes an Application for Work on Restorative Technologies.

Juvenile Division inspectors helped to identify a circle of problems, using which they can work on restorative technologies with minors and their parents / legal representatives. The Juvenile Division inspector, who submitted the application, is the curator of the case 
of the restorative work with a specific family carried out by the TRS:

- makes organizational calls;

- provides an initial visit to a minor and their parents by specialists of the department, as well as other persons who are significant people for the minor, and whose participation in restoration work is important and appropriate;

- provides interaction with guardianship authorities, centres of social assistance to the population, educational organizations and organizations of additional education;

- monitors the implementation of family agreements based on the results of the restorative program.

TRS specialists organize the work process, implementing the principles of the restorative approach. After receiving the application, they sequentially hold individual preliminary restorative meetings with possible participants in the program (including the case curator): the minor, parents / legal representatives of the minor, people who are significant for a minor (relatives, friends, specialists of social services, educational organizations); representatives of the local community and social environment who know the minor, their family, and who care about the minor's fate.

At the beginning of the meeting, each participant is explained the essence and principles of restorative work on difficult family situations and situations of conflict of a minor with the law and society, the role of mediators of TRS and the responsibility of participants in resolving the situation. Then the meeting's participants are given the opportunity to tell:

- About their vision of the problem situation of the minor and his / her family, those issues that it is important for the family to solve for his / her social well-being;

- About the resources of the minor and his / her family, which they can rely on when restoring the situation;

- About people who are significant for a minor from his / her social environment who could contribute to resolving the situation;

- About their vision of possible ways to resolve the situation, what personally they are ready to do for this.
In conclusion, it is proposed to take part in resolving a difficult life situation in a restorative way through participation in the restorative programma (Family conference, Family circle, and Restorative family mediation), its rules and procedure, the role of all participants and mediators are explained, a written consent is taken.

After that, the TRS specialists select the technology and develop a model of collaboration with all participants (both family members and significant people whose participation is significant in resolving the situation), determine the date and time of the joint meeting. The duration of the restorative work on a particular case depends on the complexity of the case, the number of participants, the number and types of restorative programmes. TRS specialists inform the Juvenile Division inspector about this (so that administrative decisions are applied taking into account the terms of the program).

Depending on the situation, TRS specialists can conduct the following restorative programmes with their families: Family mediation; Family conference; Restorative mediation; Community circles. We describe some of the individual restorative programmes.

Family Conference is a restorative programma for working with the family in a difficult life situation (including those associated with deviant behaviour, neglect and juvenile delinquency). FC is a process in which the family itself remains the master of the problem, they are provide with the opportunity to make a decision on their own by consensus and implement it, if necessary, involving specialists (except representatives of the immediate social environment; social workers and representatives of the prevention system can participate in it). It is important that all significant members of the extended family and people close to family and the child who are able to help him study, organize treatment and leisure participate in the FC. FC allows activating the potential of the family and the immediate social environment to develop an independent solution to overcome the crisis situation in the family (Maksudov, 2017; Metodicheskie rekomendatsii po vnedreniiu..., 2017; Mod- 
ellnoe opisanie programmy..., 2017; Page, 2011).

- Family Mediation allows resolving the conflict between the minor and their parents / legal representatives, brothers and sisters, between the parents themselves. It helps to focus on the individual needs and feelings of participants, to develop a scheme by which their relations will be built in the future (Parkinson, 2010).

The agreements reached during the restorative programma, the decision or plan drawn up at the Family council, are recorded by the TRS specialists in the language that is clear for the participants themselves.

At the end of the restorative programma, TRS specialists draw up an agreement / plan, which is signed by all participants. One copy is handed over to the family, another one is given to the inspector of the Juvenile Division, who submitted the application and supervises the case (to monitor the implementation), and one more remains in the TRS.

Since July 2018, juvenile inspectors have sent 13 cases to the TRS related to the following problems of minors and their families that led to registration with the Juvenile Division: leaving home, spending the night out of home, refusing to live with parents; theft from relatives; hijacking a vehicle; drinking alcohol by parents; conflicts in the family.

In all the cases transferred, restorative work was started. 54 people became its participants: minors themselves - 11 people; their parents / legal representatives - 18 people; relatives and significant people from the immediate environment - 16 people; specialists in education and social services, including inspectors of the Juvenile Division 7 people.

By the beginning of 2020, the work on 13 cases had been completed: successfully completed or interrupted at the initiative of the participants. In 10 cases, the situation is fully or partially resolved and agreements are reached, where 6 cases finished with the full resolution of the situation and 4 cases finished with neutralization of the conflict. In these cases, the inspectors transferred the agreements reached to the police departments.
In two cases, participants refused restorative work, preferring other forms of resolution or development of the situation. Parents of minors refused to work, as they hoped that the department's specialists would have such an impact on their child that he / she would fulfil their requirements, change his / her behaviour, and they themselves would not change anything in the relationship, and would not take into account the opinion and needs of a child. These families were sent to work for psychologists of the Kuzbass Regional Centre for Psychological, Medical and Social Care. In one case, family members, after visiting the TRS and the preliminary restorative conversation, were able to independently agree on controversial issues. The Juvenile Division inspectors were given protocols with a brief description of the restoration work carried out by the TRS specialists.

The conditions for successful work of TRS specialists are an independent position of TRS, maintaining the principles of the restorative approach, following certain stages of work, maintaining their professional position and managing the development of the situation among people emotionally involved in a conflict situation, certain professional skills of organization and communication, transferring responsibility to the participants in the situation, etc. (Konovalov, 2017).

In the process of the restorative work, participants in conflict / criminal situations may experience the birth / restoration of mutual understanding, and on this basis, the transformation of the vision of the situation; acceptance of responsibility for the situation, their contribution to its creation and correction; joint search for a solution to correct and prevent a recurrence of the situation; liberation from negative emotional states (guilt, shame, fear, desire to take revenge, etc.); restoration of a healthy identity (getting rid of the intrapersonal status of Victim and Offender) and the end of hostility, rehumanization as the restoration of humanity in a relationship; restoration / gaining control over one's life, getting rid of learned helplessness; restoration of a responsible position of adults (professional, parental); sincere repentance 
and forgiveness (it can happen, but even apologizing and accepting can be enough); restoration of the victim's sense of integrity and justice of the world violated by the situation of harming the victim; restoration of a sense of security, trust in the world and people, violated by the situation of causing harm, etc. (Zehr, 1998; Maksudov, 2017; Karnozova, 2014; Konovalov, 2017).

A qualitative analysis of mediators' self-reports and feedback from participants in restorative programs on complex family, school and criminal situations involving minors shows that they begin to hear and understand each other, perceive the decision as fairly, get rid of mutual resentment, feel respect for themselves and others, in the future they do not repeat what they have done and resort to peaceful means of resolving situations (L. Karnozova, A. Konovalov, monitoring the activities of reconciliation services, published in the journal "Bulletin of Restorative Justice" for 2014 - 2019 years). That is, certain personality dynamics and a change in their social behaviour are noted.

An analysis of the results of our study showed that even in the case of incomplete restorative programmes, positive changes were observed in the behaviour of individual participants and the situation as a whole:

- Participants in the situation sometimes for the first time openly express things that are important for themselves to each other (their needs, feelings, wishes, points of view, and painful moments in communication);
- Hear sometimes for the first time a loved one (their child, parent, relative), aspects important to them;

- There is an understanding of their own behaviour and those moments that cause pain and suffering to relatives, other people;

- There is a change in the way parents communicate with their child; the child communicates with his / her parents;

- A more responsible attitude of a minor to his / her behaviour, its consequences, and his / her future is born.

Thus, an analysis of the results of a pilot empirical study on the testing of technologies developed by the authors shows their effectiveness in relation to complex school and family conflict situations. Given special training in restorative technologies and an organizational structure uniting trained restorative practitioners that is TRS, these algorithms can be applied by specialists in the social sphere, education system, juvenile delinquency prevention and neglect system, helping to reduce aggression, social tension and establish constructive ways of social interaction in educational space and society as a whole through the introduction of new ways to react to conflicts and problem situations on the basis of dialogue, peaceful settlement and a restorative culture of relations, as well as assistance in the prevention of crime and social rehabilitation of participants in conflict and criminal situations based on the principles of a restorative approach / justice.

\section{References}

Belonogova, E.V. (2019). Dizain vosstanovitel'noi programmy po situatsii slozhnogo mnogourovnevogo konflikta $\mathrm{v}$ stadii eskalatsii $\mathrm{v}$ obrazovatel'noi organizatsii [The design of the restorative program for the situation of a complex multi-level conflict at the stage of escalation in the educational organization]. In Mediatsiia v obrazovanii: polikul'turnyi kontekst: materialy 1 Mezhdunar. nauch. konf. Krasnoiarsk, 24-26 oktiabria 2019 g. pod obshch. red. O.G. Smolianinovoi [Mediation in Education: Multicultural Context: Materials of the $1^{\text {st }}$ International Research-to-Practice Conference. Krasnoyarsk, October 24-26, 2019 edited by O.G. Smolyaninova]. Siberian Federal University, 13-20.

Braithwaite, J. (2002). Prestuplenie, styd i vossoedinenie [Crime, shame and Reintegration]. Moscow, MOO Centre "Judicial and Legal Reform", $310 \mathrm{p}$.

Christie, N. (2007). Konflikty kak sobstvennost' [Conflicts as property]. In Vosstanovitel'naia iuvenal'naia iustitsiia. Sost. A.Iu. Konovalov [Restorative juvenile justice. Collected by A.Iu. Konovalov]. Moscow, MOO Centre "Judicial Legal Reform”, 40-58. 
Costello, B., Wachtel, J., Wachtel, T. (2009). The Restorative Practices Handbook for Teachers, Disciplinarians and Administrators (Building a culture of community in schools). Bethlehem, PA: International Institute for Restorative Practices.

Karnozova, L.M. (2014). Vvedenie v vosstanovitel'noe pravosudie (mediatsiia v otvet na prestuplenie). Monografiia [Introduction to restorative justice (mediation in response to crime). Monograph]. Moscow, Prospect, $264 \mathrm{p}$.

Konovalov, A.Iu. (2017). Gorodskaia sluzhba primireniia v sisteme obrazovaniia Moskvy [City reconciliation service in the educational system of Moscow]. In Vestnik vosstanovitel'noi iustitsii (20 let vosstanovitel'nomu pravosudiiu $v$ Rossii) [Bulletin of restorative justice (20 years of restorative justice in Russia)], 14. Moscow, MOO Centre "Judicial and Legal Reform", 68-76.

Konovalov, A.Iu. (2017). Shkol'naia sluzhba primireniia i vosstanovitel'naia kul'tura vzaimootnoshenii: prakticheskoe rukovodstvo [The School Reconciliation Service and Restorative Culture of Relations: A Practical Guide]. Tomsk, MOO Centre "Judicial and Legal Reform", 264 p.

Maksudov, R.R. (2017). Programmy vosstanovitel'nogo razresheniia konfliktov i kriminal'nykh situatsii: ot unikal'nykh epizodov $k$ zazhivleniiu sotsial'noi tkani [Programs for restorative resolution of conflicts and criminal situations: from unique episodes to the healing of social tissue]. Tomsk, MOO Centre "Judicial and Legal Reform", $256 \mathrm{p}$.

Metodicheskie rekomendatsii po vnedreniiu vosstanovitel'nykh tekhnologii ( $v$ tom chisle mediatsii) $v$ vospitatel'nuiu deiatel'nost' obrazovatel'nykh organizatsii (Pis'mo Minobrnauki ot 26.12.2017 № 07-7657) [Methodological recommendations on the introduction of restorative technologies (including mediation) in the educational activities of educational organizations (Letter of the Ministry of Education and Science of December 26, 2017, No. 07-7657)].

Metodicheskie rekomendatsii po sozdaniiu i razvitiiu sluzhb primireniia $v$ obrazovatel'nykh organizatsiiakh (Pis'mo Minobrnauki ot 18.12.2015 № 07-4317) [Methodological recommendations on the creation and development of reconciliation services in educational organizations (Letter of the Ministry of Education and Science dated of December 18, 2015, No. 07-4317)].

Model'noe opisanie programmy «Semeinaia konferentsiia» dlia spetsial'nykh uchebno-vospitatel'nykh uchrezhdenii: Metodicheskoe posobie / Avt.-sostaviteli: R. Maksudov, L. Karnozova, A. Konovalov, E. Belonogova i dr. [Model description of the "Family Conference" programma for special educational institutions: Toolkit. Authors: R. Maksudov, L. Karnozova, A. Konovalov, E. Belonogova and others] (2017). Moscow, MOO Centre "Judicial and Legal Reform". Kaltan, Kaltansky SUVU, 203 p.

Page, R. (2011). Semeinye gruppovye konferentsii: etapy provedeniia [Family group conferences: stages of conducting]. In Vestnik vosstanovitel'noi iustitsii (Razvitie arsenala vosstanovitel'nykh praktikv rabote s konfliktnymi i kriminal'nymi situatsiiami) [Bulletin of Restorative Justice (Development of an arsenal of restorative practices in working with conflict and criminal situations)], 8. Moscow, MOO "Judicial and Legal Reform", 91-96.

Parkinson, L. (2010). Semeinaia mediatsiia [Family mediation]. Moscow, Interregional Centre for Management and Political Consulting, $400 \mathrm{p}$.

Pranis, K., Stuart, B., Wedge, M. (2010). Krugi primireniia: ot prestupleniia k soobshchestvu [Circles of reconciliation: from crime to the community]. Moscow, MOO Centre "Judicial and Legal Reform", $240 \mathrm{p}$.

Territorial'nye sluzhby primireniia: usloviia funktsionirovaniia i organizatsionnoe ustroistvo. Sbornik materialov. Sost. L.M. Karnozova [Territorial reconciliation services: operating conditions and organizational structure. Sourcebook. Composed by L.M. Karnozova] (2015). Moscow, MOO Centre "Judicial and Legal Reform", $184 \mathrm{p}$.

Vosstanovitel'nye programmy v rabote s det'mi i sem'iami, nakhodiashchimisia v trudnoi zhiznennoi situatsii. Rabota s trudnymi sluchaiami (sbornik materialov) [Restorative programs in working with children and families in difficult situations. Work with difficult cases (source book)] (2018). Moscow, MOO Centre "Judicial and Legal Reform", 142 p.

Zehr, H. (1998). Vosstanovitel'noe pravosudie: novyi vzgliad na prestuplenie i nakazanie [Restorative justice: a new look at crime and punishment]. Moscow, MOO Centre "Judicial and Legal Reform", 328 p. 


\section{Алгоритмы медиативной восстановительной работы территориальной службы примирения \\ по сложным случаям}

\section{Е.В. Белоногова, Н.Г. Прокопьева \\ Отдел медиации и восстановительных практик \\ Государственной организации образования \\ «Кузбасский региональный цуентр психолого-педагогической, медицинской и социчальной помощуи «Здоровье и развитие личности» Российская Федерация, Кемерово}

Аннотация. В статье представлен опыт Территориальной службы примирения Кемеровской области по разработке и апробации алгоритмов медиативного разрешения сложных школьных и семейных ситуаций несовершеннолетних на основе принципов восстановительного подхода. Для восстановительной работы с многоуровневыми конфликтами в стадии эскалации в образовательных организациях, а также с трудными жизненными ситуациями несовершеннолетних и их семей, состоящих на учете в отделениях по делам несовершеннолетних, были выработаны специальные социальные технологии, имеющие комплексный дизайн и включающие различные восстановительные программы (восстановительная медиация, круг сообщества, школьно-родительский совет, семейная групповая конференция, семейная медиация). Анализ результатов пилотной эмпирической апробации разработанных авторами технологий показывает их результативность в отношении сложных школьных и семейных конфликтных ситуаций. При наличии специальной подготовки по восстановительным технологиям и организационной структуры, объединяющей обученных восстановительных практиков (Территориальной службы примирения), данные алгоритмы могут применяться специалистами социальной сферы, системы образования, системы профилактики правонарушений и безнадзорности несовершеннолетних.

Ключевые слова: сложный многоуровневый конфликт, Территориальная служба примирения, медиативный метод, восстановительный подход, принципы восстановительного правосудия, восстановительная программа, круг сообщества, семейная конференция, школьно-родительский совет, семейная медиация, восстановительная медиация.

Научная специальность: 22.00.00 - социологические науки. 